\title{
THE INFLUENCE OF GENETIC PROVENIENCE ON METABOLIC BLOOD PROFILE OF DAIRY COWS
}

\author{
Z. Spasić, B. Milošević, Z. Ilić, Lj. Anđušić, S. Ćirić, N. Lalić \\ Faculty of Agriculture, Kosovska Mitrovica, Republic of Serbia \\ Corresponding author: spasic.zvonko@gmail.com \\ Original scientific paper
}

Abstract: Availability of easily accessible methods and apparatus for establishing the essential parameters that indicate physiological status of animals at different stages of productive life may have greater application in daily controls on smaller farms in order to remove, in time, the causes and consequences of disturbances in the reproductive and productive cycle of cows. Two groups were formed, Domestic spotted cattle and Red Holstein, and in the blood serum from tested animals following parameters were determined: glucose, urea, total bilirubin, aspartate aminotransferase (AST), glutamate dehydrogenase (GLDH), and inorganic phosphorus. Determined glucose concentration of $2,97 \mathrm{mmol} / \mathrm{L}$ in redholstein cows is within physiological range, while in domestic spotted cows it is in hypoglycemia $(1,14 \mathrm{mmol} / \mathrm{L})$. Statistical significance also demonstrate derived concentrations in different genotypes of blood urea $(3,42: 4,90 \mathrm{mmol} / \mathrm{L})$ and GLDH (12,19 : 5,76 IU/L).Differences in concentrations of certain parameters of the examined blood serum, and variations amplitude that occur between groups, as well as statistical analysis of results and the test of significance, just confirm the hypothesis that for each animal breed, reference values related to narrow distribution area of growing should be established.

Key words: cows, domestic spotted cattle, red Holstein, metabolic profile

\section{Introduction}

In recent years, there was a significant restructuring of our livestock production. There is an increasing number of farmers who grow five or more cows. This tendency to increase milk production, often results in exclusion of cows from the herd, due to health and fertility disorders, which produces significant financial burdens. Prolongation of the conception and long service periods, caused by physiological disorder by one, and negative consequences arising from the genetic inferiority of their herds and low milk production, on the other side, there is a small possibility for improvement of the selection process. 
Given that the fertility traits are of very complex nature Lotthammer (1991) and Williamson (1986) state that the therapeutic and prophylactic measures have to be applied to the entire herd rather than to individuals in a herd, namely, the herd is a patient. Since sick animals are mostly under therapy, there is little time remaining for the prophylaxis and preventive measures, which are certainly cheaper and more efficient compared to the treatment of sick animals.

Therefore, such a control of a herd basically relays on biochemical testing (prophylaxis of metabolic disorders) which with proper selection and zootechnic measures, aims and can give results through advice and help to herd owners to maintain and improve the health of their cows alongside production increase.

\section{Materials and Methods}

The test included 65 cows from three herds, as follows, 27 cows of red Holstein breed on an average 4.2 years old and 38 domestic spotted cows, on an average 4.6 years old. Average milk production in standard lactation was $6020 \mathrm{~kg}$ in red-Holstein breed, while in Simmental type cows for the same period of testing, milk yield averaged $4530 \mathrm{~kg}$.

During the study cows were placed in closed stalls. Feeding and care were in accordance with the intended use and exploitation of animals. Blood samples for analysis of observed parameters, were taken by jugular vein puncture. After the spontaneous coagulation of blood in tubes serum was separated at room temperature. Drained supernatant was centrifuged at $3000 \mathrm{rpm}$.

All biochemical parameters were determined by commercial tests of the "Human" company on an automatic analyzer "HITACHI 705".

The concentration of glucose, total bilirubin, and inorganic phosphorus was determined by spectrophotometry.

The activity of the enzyme glutamate dehydrogenase (GLDH), aspartate aminotransferase (AST) and urea content, were measured by the change in the amount of adsorbed substrate in UV range derived under the influence of appropriate enzymes in NAD-NADH reaction.

The results of the research were analyzed using ANOVA and differences tested using t-test (Spasić et al. 2006).

\section{Results and Discussion}

Glucose in the blood stream is in free form in a narrow physiological range ( 2.2 to 3.5 mmol-L, Sretenović et al., 2010), because the body tends to maintain its constant level with several regulatory mechanisms. Hypoglycemia indicates a negative energy balance, due to insufficient input of nutrients rich in 
carbohydrates. At the same time this is also a sign of liver stress and in cows with poor fertility results lower blood glucose levels were determined.

Variation of blood glucose concentration of tested cows has been shown in Table. 1

Determined glucose concentration of $2,97 \mathrm{mmol} / \mathrm{L}$ in redholstein cows is within physiological range, while in domestic spotted cows it is in hypoglycemia and derived glucose difference of $1,83 \mathrm{mmol} / \mathrm{L}$ in two different genotypes is statistically highly significant $\left(\mathrm{t}_{\mathrm{exp} .}=9,654^{* *}\right)$.

Table 1. The average concentration of glucose in the blood of cows $(\mathrm{mmol} / \mathrm{L})$

\begin{tabular}{|l|c|c|c|c|c|}
\hline HERD & $\begin{array}{c}\text { Number } \\
\text { of heads }\end{array}$ & $\bar{x} \pm s_{\bar{x}}$ & SD & CV\% & Min. - Max. \\
\hline Red holstein & 27 & $2,97 \pm 0,48$ & 0,53 & 17,8 & $2,02-4,08$ \\
\hline $\begin{array}{l}\text { Domestic } \\
\text { spotted }\end{array}$ & 38 & $1,14 \pm 0,30$ & 0,34 & 29,8 & $1,36-2,12$ \\
\hline
\end{tabular}

As a result of efforts to increase milk production, often resorting to increased or uncontrolled haylage application and concentrate mixtures in dairy cows diet, which increase the danger of protein excess with hyper uremia potential.

Physiological values of urea in blood serum ranging from 4.16 to 5.28 $\mathrm{mmol} / \mathrm{L}$ (Llamazares 1988) and from the table no.2. it can be seen that in Red Holstein cows hypo uremia was pronounced.

Table 2. The average concentration of urea in the blood of cows $(\mathrm{mmol} / \mathrm{L})$

\begin{tabular}{|l|c|c|c|c|c|}
\hline HERD & $\begin{array}{c}\text { Number } \\
\text { of heads }\end{array}$ & $\bar{x} \pm s_{\bar{x}}$ & SD & CV\% & Min. - Max. \\
\hline Red holstein & 27 & $3,42 \pm 0,38$ & 1,18 & 34,5 & $1,40-6,10$ \\
\hline Domestic spotted & 38 & $4,90 \pm 0,17$ & 1,32 & 26,9 & $2,04-6,29$ \\
\hline
\end{tabular}

Difference of $1,48 \mathrm{mmol} / \mathrm{L}$ that is determined in favor of domestic spotted cows statistically is very significant $\left(\mathrm{t}_{\text {exp. }}=3,153^{* *}\right)$, along with constatation that within the breed there are heads with extreme low glucose concentration, merely $1,4 \mathrm{mmlol} / \mathrm{L}$.

Increased levels of total bilirubin in blood serum usually occurs in highly productive cows accompanied by a low concentration of glucose in the blood. This leads to a condition with acute liver stress, followed by the energy deficit. Jovanovic et al. (1987) found that the average value of bilirubinemia in cows 10 to 15 days before calving is $4.7 \mathrm{mmol} / \mathrm{L}$, and postpartum level is slightly higher $(5.4$ $\mathrm{mmol} / \mathrm{L}$ ), and subsequently concentration declines. 
Table 3. The average content of total bilirubin in the blood of cows $(\mu \mathrm{mol} / \mathrm{L})$

\begin{tabular}{|l|c|c|c|c|c|}
\hline HERD & $\begin{array}{c}\text { Number } \\
\text { of heads }\end{array}$ & $\bar{x} \pm s_{\bar{x}}$ & SD & CV\% & Min. - Max. \\
\hline Red holstein & 27 & $3,76 \pm 0,24$ & 1,04 & 27,6 & $0,90-8,40$ \\
\hline Domestic spotted & 38 & $4,38 \pm 0,18$ & 1,12 & 25,5 & $1,20-6,90$ \\
\hline
\end{tabular}

Bilrubin values variate within the physiologically defined borders and obtained differences among the populations of cows are not statistically significant $\left(\mathrm{t}_{\text {exp. }}=1,032^{\mathrm{NS}}\right)$. As it was found regarding the urea blood concentration, there are also heads here with extreme low $(0,9 \mu \mathrm{mol} / \mathrm{L})$ amount of blood bilirubin, as well as double higher amounts than those regarded normal. If this condition would have continued, certainly could increase the risk of liver damage that for consequence may have overall metabolism disruption.

In diagnosis of health and fertility disorders of cows, AST is used as a parameter for assessing the functional state of the liver, because other liver parenchyma damage and skeletal muscle are rare. At with liver damage blood AST responds later than the bilirubin, but increased values of this enzyme in the blood remain longer (Dehning, 1981)

Table 4. The average concentration of AST in the blood of cows (IU/L)

\begin{tabular}{|l|c|c|c|c|c|}
\hline HERD & $\begin{array}{c}\text { Number } \\
\text { of heads }\end{array}$ & $\bar{x} \pm s_{\bar{x}}$ & SD & CV\% & Min. - Max. \\
\hline Red holstein & 27 & $49,7 \pm 1,78$ & 8,28 & 16,7 & $33,7-68,2$ \\
\hline Domestic spotted & 38 & $50,56 \pm 2,03$ & 12,14 & 24,0 & $32,1-95,7$ \\
\hline
\end{tabular}

As can be seen from the results, there is a high activity of AST in both breeds of cattle in different herds, but there is no statistically significant change in the concentration of AST $(\mathrm{p}<0.05)$.

Increased concentrations of GLDH enzyme in blood serum, is an indicator of severe damage to liver parenchyma. This increased GLDH activity occurs in three to five weeks after increase of AST values (Wemheuer 1987).

Table 5. The average concentration in the blood of cows GLDH (IU/L)

\begin{tabular}{|l|c|c|c|c|c|}
\hline HERD & $\begin{array}{c}\text { Number } \\
\text { of heads }\end{array}$ & $\bar{x} \pm s_{\bar{x}}$ & SD & CV\% & Min. - Max. \\
\hline Red holstein & 27 & $12,19 \pm 0,84$ & 10,52 & 86,3 & $4,01-54,30$ \\
\hline Domestic spotted & 38 & $5,76 \pm 0,13$ & 4,09 & 71,3 & $1,39-15,60$ \\
\hline
\end{tabular}

GLDH activity was increased above the physiological limits in a herd of red Holstein cows. The difference of $6.43 \mathrm{IU} / \mathrm{L}$ in both breeds studied was statistically significant $\left(\mathrm{t}_{\text {exp. }}=2,218^{*}\right)$. 
In the literature can be found that physiological concentrations of inorganic phosphorus levels are in the range of 1.60 to $2.30 \mathrm{mmol} / \mathrm{L}$. at that it should be emphasized that diet of dried and lactating cows with well-balanced meals conclusively influence the maintenance of calcemia and phosphatemia in the physiological range, despite the emerging needs of the organism (Jovanovic et al., 1987).

The surplus of phosphorus is expressed primarily in the development of purulent endometritis, and irregular estrus because of functional disturbances in the ovaries (Scholz, 1991).

Table 6. The average content of inorganic phosphorus in the blood of cows ( $\mathrm{mmol} / \mathrm{L}$ )

\begin{tabular}{|l|c|c|c|c|c|}
\hline HERD & $\begin{array}{c}\text { Number } \\
\text { of heads }\end{array}$ & $\bar{x} \pm s_{\bar{x}}$ & SD & CV\% & Min. - Max. \\
\hline Red holstein & 27 & $2,59 \pm 0,41$ & 0,37 & 14,3 & $1,94-3,19$ \\
\hline Domestic spotted & 38 & $2,33 \pm 0,37$ & 0,41 & 17,6 & $1,44-3,09$ \\
\hline
\end{tabular}

Weakly expressed hyperphosphatemia in Red Holstein cows in relation to physiological values in Domestic spotted cows is not statistically significant $(\mathrm{p}<0.05)$.

\section{Conclusion}

On the basis of conducted examination and results obtained, we can conclude the following:

- The existence of a significant number of cows with hyperbilirubinemia and increased activity of enzymes AST and GLDH specifically points to the functional state of liver disorders, or the existence of an increased risk of acute and chronic disorders with possible morphological appearance of ketotic state in the early puerperium.

- Red Holstein cows herd in comparison to domestic spotted Simmental had higher average glucose concentration and GLDH, while domestic spotted cattle had higher average concentration of urea in the blood.

- Early detection and prevention of certain reproduction disorders during lactation period is entirely possible by determination of metabolic profile parameters in blood serum of animals. 


\section{Acknowledgment}

We thank the Serbian Ministry of Education and Science, Republic of Serbia, for support. Project TR-31001

\section{Uticaj genetskog porekla na metabolizam krvi kod mlečnih krava}

Z. Spasić, B. Milošević, Z. Ilić, Lj. Anđušić, S. Cirić, N. Lalić

\section{Rezime}

Dostupnost lakopristupačnim metodama i aparaturi za ustanovljavanje bitnih parametara koji nam ukazuju na fiziološki status životinja u različitim fazama produktivnog života, mogu imati sve veću primenu u svakodnevnim kontrolama i na manjim farmama, a u svrhu blagovremenog otklanjanja uzroka i posledica poremećaja u reproduktivnom i proizvodnom ciklusu krava.

Formirane su dve grupe plotkinja rase domaće šarene u tipu simentalca i crveni holštajn, i iz krvnog seruma ispitivanih grla ustanovljavani sledeći parametri: glukoza, urea, ukupni bilirubin, aspartat-aminotransferaza (AST), glutamatdehidrogenaza (GLDH), i neorganski fosfor.

Ustanovljena koncentracija glukoze od 2,97 mmol/L kod crvenog holštajna je u fiziološkim granicama, dok je kod domaćeg šarenog u hipoglikemiji $(1,14$ $\mathrm{mmol} / \mathrm{L})$. Statističku značajnost pokazuju i ustanovljene koncentracije kod različitig genotipova plotkinja za ureu u krvi $(3,42: 4,90 \mathrm{mmol} / \mathrm{L})$ i GLDH $(12,19$ : $5,76 \mathrm{IU} / \mathrm{L})$.

Razlike u koncentraciji pojedinih ispitivanih parametara iz krvnog seruma, kao i amplitude variranja koje se javljaju između ispitivanih grupa, kao i statističkom obradom dobijenih rezultata i sprovedenim testom značajnosti razlika, upravo potvrđuju hipotezu da za svaku rasu gajenih životinja treba utvrditi referentne vrednosti koje se odnose na uži areal gajenja.

\section{References}

DEHNING R. (1981): Untersuchungen in Grunlandbetrieben uber Beziehugen Futterung und Gesundheits-und Fruchtbarkeitsstorungen bei Milehrinden unter Berucksichtigung von Blutserumuntersuchungen. Hanover, Tieratztl. Hochsch., Diss. 
JOVANOVIĆ J.M., STAMATOVIĆ S., ŠAMANC H., IVANOV I., RADOJIČIĆ BILJANA, DAMJANOVIĆ Z., JONIĆ B., RANĐELOVIĆ J., STEFANOVIĆ M., ARSIĆ B., PETKOVIĆ B. (1987): Prilog izučavanju metaboličkog profila krava u laktaciji. Veterinastki glasnik, 6, 449-454.

LOTTHAMMER K.H. (1991): Beziehingen zwischen eingen Blut-und Milchinhaltstoffen als Indikatoren der Energieversogung und Fruchtbarkeit soweEuter-und Stoffwechselstorungen bei Milchrunderin. Monarsh. Veterinarmed., 46, 639-643.

LLAMAZARES J.A., DOMINGEZ J.C., ANEL L. (1988): Relationship between glucose and AST concentracion in serum fertility in dairy herds. 11 Int. Kongr. Uber tier. Fortpflanz. U. kunstl. Besamung, Dublin, 2, 101.

SCHOLZ H. (1991): Beurteilung der Nahrstoffversorgung durch Parameter am Tier (Rind). Ubers. Tierernahr., 18, 137-164.

SPASIĆ Z., MILOŠEVIĆ B., MILENKOVIĆ M. (2006): Oplemenjivanje domaćih životinja - praktikum. Lešak.

SRETENOVIĆ LJ., NOVAKOVIĆ Ž., OSTOJIĆ D., PANTELIĆ V., ALEKSIĆ S., PETROVIĆ M.M., NOVAKOVIĆ M., MARINKOV G. (2010): Nova tehnologija dobijanja funkcionalne hrane-mleka i mesa poboljšanog kvaliteta. Biotechnology in Animal Husbandry, 26, spec.issue, 9-22.

WEMHEUER W. (1987): Auswertung von Blutparametern aus fruchtbarkeitsgestorterm Milchvichviehherden. Tierarztl. Prax., 15, 353-360.

WILLIAMSON N.B. (1986): The economics of reproductive herd healt programs for dairy herd. D.A. Morow: Current therapic in theriogenology, 2. Saunders. Philadelphia, 410-413. 